Aspirasi: Jurnal Masalah-Masalah Sosial | Volume 10, No. 1 Juni 2019

ISSN: 2086-6305 (print) ISSN: 2614-5863 (electronic)

DOI: https://doi.org/10.22212/aspirasi.v7il.1084

link online: http://jurnal.dpr.go.id/index.php/aspirasi/index

\title{
SANITASI DAN DAMPAKNYA BAGI KESEHATAN: STUDI DARI PESANTREN
}

\section{Sanitation and Its Impact to Health: Study from Pesantren}

\author{
Achmad Muchaddam Fahham \\ achmad.muchaddam@dpr.go.id \\ Pusat Penelitian Badan Keahlian DPR RI \\ Jl. Gatot Subroto Senayan Jakarta
}

Naskah Diterima: 30 Maret 2019 | Naskah direvisi: 21 Juni 2019| Naskah diterbitkan: 29 Juni 2019

\begin{abstract}
According to the United Nations, sanitation is one of the basic human rights. Sanitation impacts the quality of human life, including in Islamic boarding schools - institutions that organized Islamic religious education. The Islamic boarding houses should meet the sanitation standard to create a conducive environment for the students. This study was conducted using a qualitative method to determine sanitation conditions of Islamic boarding school, the impact of sanitation on the school to students' health conditions, and government policies on sanitation problems faced by the boarding school. Data collection were conducted using in-depth interviews and literature studies, which then analyzed by reducing techniques and drawing conclusions. The study concluded that most Islamic boarding schools in various regions in Indonesia do not have sanitation that met health standards. These conditions have an impact on the health of the students. Many of them have been exposed to scabies, diarrhea, and Accute Respiratory Infection (ARI). There are two government policies implemented to help Islamic boarding schools dealing with sanitation problems: boarding schools health program of the ministry of health and eco-pesantren program of the ministry of environment. However, not all Islamic boarding school have access to any one of these programs. Thus, the government needs to expand the coverage of the boarding school health program and eco-pesantren program.
\end{abstract}

Keywords: sanitation, water, scabies, eco-pesantren, and health.

\begin{abstract}
Abstrak: Menurut Perserikatan Bangsa-Bangsa sanitasi merupakan salah satu hak asasi manusia. Sanitasi memengaruhi kualitas hidup manusia, termasuk di pesantren yang merupakan institusi penyelenggaran pendidikan keagamaan Islam. Di pondok tempat tinggal santri seyogyanya memenuhi standar sanitasi agar santri dapat beraktivitas dengan nyaman sesuai dengan tuntunan Islam. Studi ini dilakukan dengan metode kualitatif untuk mengetahui kondisi sanitasi pesantren, dampak sanitasi pesantren terhadap kesehatan santri, dan kebijakan pemerintah terhadap masalah sanitasi yang dihadapi oleh pesantren. Pengumpulan data dilakukan dengan wawancara mendalam dan studi literatur, yang kemudian dianalisis dengan teknik reduksi dan penarikan kesimpulan. Studi ini menyimpulkan bahwa sebagian besar pesantren di berbagai wilayah di Indonesia belum memiliki sanitasi yang memenuhi syarat kesehatan. Kondisi sanitasi yang belum memenuhi syarat kesehatan tersebut memiliki dampak bagi kesehatan santri. Banyak santri yang pernah terkena skabies, diare, dan Infeksi Saluran Pernapasan Akut (ISPA). Ada dua kebijakan pemerintah yang dilaksanakan untuk membantu pesantren keluar dari masalah sanitasi yang dihadapinya, yakni Pos Kesehatan Pesantren dari Kementerian Kesehatan dan eco-pesantren Kementerian Lingkungan Hidup dan Kehutanan. Namun, belum semua pesantren dapat mengakses salah satu kebijakan tersebut. Untuk itu, Pemerintah perlu meningkatkan jangkauan program pos kesehatan pesantren dan eco-pesantren.
\end{abstract}

Kata kunci: sanitasi, air, skabies, eco-pesantren, dan kesehatan. 


\section{Pendahuluan}

Pondok pesantren merupakan salah satu institusi pendidikan keagamaan Islam tertua di Indonesia. Karena itu dari sisi historis, pesantren tidak hanya identik dengan makna keislaman, tetapi juga mengandung makna keaslian Indonesia (Madjid, 1997: 17). Menurut Data Emis 2015/2016, jumlah pondok pesantren yang besar dan tersebar di seluruh provinsi di Indonesia sebanyak 28.984 pondok pesantren dengan jumlah santri sebanyak 4.290.626. Dilihat dari sisi fungsinya, pesantren memiliki tiga fungsi utama, yakni fungsi pendidikan, dakwah keagamaan, dan pemberdayaan sosial. Fungsi pesantren yang saat ini paling menonjol adalah fungsi pendidikan. Fungsi ini punya ciri khas yang membedakan pesantren dengan lembaga pendidikan keislaman lainnya. Ada tiga elemen yang membentuk ciri khas pendidikan pesantren, pertama, pola kepemimpinan pesantren yang mandiri; kedua, literatur keagamaan yang digunakan yang lazim disebut sebagai kitab kuning; dan ketiga tata nilai yang dianut. Berdasar tiga elemen tersebut, Wahid (1997:10) menyebut pesantren sebagai subkultur.

Anak yang mengenyam pendidikan di pesantren disebut dengan santri. Umur mereka rata-rata berada di kisaran 7 sampai 18 tahun. Dari sisi usia itu, santri merupakan anak yang sedang mengalami proses tumbuh kembang. Mereka berhak memperoleh sanitasi yang layak. Perserikatan Bangsa Bangsa pada 2010 bahkan telah menetapkan akses terhadap sanitasi yang layak sebagai hak asasi manusia, karena sanitasi yang buruk memiliki dampak pada kesehatan anak (Suanta, 2016:120). Santri yang belajar di pesantren, mayoritas tinggal di asrama pesantren. Sebagai tempat hunian santri, asrama pesantren pada umumnya dilengkapi berbagai fasilitas seperti kamar mandi, jamban, dapur, dan tempat sampah. Ketersediaan fasilitas demikian guna mendukung sistem kehidupan asrama pesantren yang dinamis. Pola pendidikan berbasis asrama pesantren tersebut kerap kali melahirkan gangguan kesehatan bagi santri. Bermacammacam gangguan kesehatan sering muncul diderita santri di pesantren, di antaranya adalah skabies, batuk, sesak nafas, influenza (Bahraen, 2012: 1) dan infeksi saluran pernafasan akut (ISPA) (Surahmawati \& Rusmin, 2015: 84-91). Gangguan kesehatan yang sering muncul di pesantren tersebut dinilai merupakan dampak dari sanitasi pesantren yang kurang sehat (Ibadurrahmi, Veronika, \& Nugrohowati, 2016: 33-45).

Studi ini dilakukan untuk memahami kondisi sanitasi pesantren, dampak sanitasi pesantren terhadap kesehatan santri dan kebijakan yang telah digulirkan pemerintah untuk meningkatkan kualitas sanitasi pesantren. Data-data yang diperlukan dikumpulkan melalui studi pustaka dan studi lapangan. Studi pustaka digunakan untuk mengumpulkan berbagai hasil penelitian tentang sanitasi pesantren, gangguan kesehatan di pesantren dan pos kesehatan pesantren serta EcoPesantren. Sementara studi lapangan digunakan untuk melakukan wawancara mendalam dengan pengelola pesantren, pengasuh, ustaz, dan pengurus santri. Data yang telah dikumpulkan melalui dua teknik pengumpulan data tersebut kemudian dianalisis dengan teknik reduksi, penyajian, dan penarikan kesimpulan (Bungin, 2018: 161).

\section{Sanitasi Pesantren}

Secara sederhana sanitasi dapat diartikan sebagai usaha pemeliharaan kesehatan. Bisa juga diartikan sebagai upaya-upaya yang dilakukan untuk menjaga kesehatan lingkungan (Marsanti, 2018: 12). Menurut Chandra (2007: 2) sanitasi merupakan upaya-upaya yang dilakukan individu atau masyarakat untuk mencegah terjadinya gangguan kesehatan yang disebabkan faktor-faktor lingkungan eksternal manusia. Bagi Riyadi (2016: 98) sanitasi merupakan upaya-upaya yang dilakukan untuk menjaga kebersihan dan kesehatan lingkungan. Pendek kata sanitasi adalah upaya yang dilakukan untuk menjaga kebersihan dan kesehatan lingkungan agar tidak muncul gangguan kesehatan. Karena itu sanitasi pesantren dapat dimaknai sebagai segala upaya yang dilakukan oleh santri atau pengelola pesantren untuk menjaga kebersihan dan kesehatan lingkungan pesantren agar tidak 
muncul gangguan kesehatan bagi santri dan pengelola pesantren. Studi-studi tentang sanitasi pesantren menjelaskan bahwa ada tiga aspek utama yang ditelaah dalam konteks sanitasi pesantren, yakni lingkungan, bangunan, dan fasilitas sanitasi. Telaah terhadap tiga aspek itu dalam studi-studi sanitasi pesantren ditujukan untuk mendeskripsikan bahwa lingkungan, bangunan, dan fasilitas sanitasi yang ada di pesantren telah memenuhi syarat kesehatan, atau sebaliknya tiga aspek itu justru belum memenuhi syarat kesehatan.

Studi-studi tentang sanitasi pesantren pada umumnya menggunakan pedoman penilaian kesehatan lingkungan, bangunan dan fasilitas sanitasi (Febriani dkk, 2016). Penilaian aspek kesehatan lingkungan, difokuskan pada lokasi dan lingkungan pesantren. Pada kedua aspek tersebut dilihat apakah lokasi pesantren terhindar dari pencemaran dan tidak terletak di daerah banjir, apakah lingkungan pesantren bersih dan indah, tidak memungkinkan menjadi tempat bersarang atau berkembang biak serangga dan tikus, pesantren memiliki pagar atau batas yang jelas, dan memiliki tempat parkir.

Pada aspek kesehatan bangunan, penilaian difokuskan pada kondisi lantai, dinding, atap dan talang, langit-langit, tangga, pintu, jendela, pencahayaan, dan kamar tidur. Pertanyaan yang diajukan untuk berbagai variabel tersebut adalah apakah lantai bersih, bahan kuat, kedap air, permukaan rata, tidak licin, dan tidak menjadi genangan air? Apakah dinding bersih, kedap air, mudah dibersihkan, dan berwarna terang? Apakah atap dan talang tidak bocor dan tidak terjadi genangan air. Apakah tinggi langit-langit dari lantai mencapai minimal 2,75 m, bersih dan berwarna terang? Apakah lebar anak tangga minimal $30 \mathrm{~cm}$, tinggi anak tangga maksimal $20 \mathrm{~cm}$, memiliki pegangan tangan, serta lebar tangga lebih dari $150 \mathrm{~cm}$ ? Apa pintu dapat dibuka, ditutup dan dikunci dengan baik, dapat mencegah masuknya binatang pengganggu? Dinilai juga kualitas jendela yang dapat dibuka dan ditutup dengan arah bukaan keluar, serta dilengkapi dengan gorden. Untuk pencahayaan ruang tamu seluas $9 \mathrm{~m}^{2}$ setidaknya sebesar 60 watt, lampu baca sebesar 40 watt. Untuk kamar tidur luas $9 \mathrm{~m}^{2}$ dibutuhkan pencahayaan 40 watt, sementara untuk lampu tidur sebesar 10 watt. Ruang dapur seluas $4 \mathrm{~m}^{2}$ seharusnya diterangi lampu 40 watt, kamar mandi/WC minimal $3 \mathrm{~m}^{2}$ dengan penerangan 25 watt. Kondisi ruang juga tidak pengap, tidak berbau, dan tidak bising. Kamar tidur, peralatan tidur bersih, penataan barang-barang rapi, kapasitas per orang $4,5 \mathrm{~m}^{2}$, serta memiliki lubang ventilasi minimal 15\% dari luas lantai.

Pada aspek fasilitas sanitasi, penilaian dilakukan untuk melihat kondisi air, tempat wudhu, sarana pembuangan air limbah, toilet/ kamar mandi/urinoir, sarana pembuangan sampah, ruang makan, dapur, dan fasilitas sanitasi bebas dari jentik nyamuk. Pertanyaan yang diajukan dalam melihat fasilitas sanitasi tersebut adalah apakah tersedia air bersih dalam jumlah cukup, apakah kualitas air memenuhi persyaratan kesehatan, jarak sarana air memenuhi persyaratan kesehatan, jarak sarana air bersih dengan sumber pencemaran minimal $10 \mathrm{~m}$ ? Apakah tempat wudhu bersih terpelihara, menggunakan air yang mengalir, tempat wudhu terpisah antara pria dan wanita, dan tersedia dalam jumlah yang cukup?

Sarana pembuangan air limbah memiliki pengelolaan air limbah, air limbah mengalir dengan lancar, saluran air limbah dibuat dengan sistem tertutup, sarana air limbah kedap air. Toilet/ kamar mandi/urinoir memiliki penampungan kotoran dengan jarak minimal $10 \mathrm{~m}$ dari sumber air, toilet/kamar mandi/urinoir bersih dan tidak berbau, letaknya tidak berhubungan langsung dengan dapur, kamar tidur, dan ruang tamu. Idealnya, setiap penambahan 10 orang ditambah 1 kamar mandi dan jamban.

Tabel 1. Perbandingan jumlah santri dengan kamar mandi/jamban

Jumlah santri Jumlah kamar mandi (unit)

\begin{tabular}{ll}
\hline $1-9$ & 1 \\
$10-19$ & 2 \\
$20-29$ & 3 \\
$30-39$ & 4 \\
$40-49$ & 5 \\
$50-60$ & 6 \\
\hline
\end{tabular}


Standar sanitasi pesantren juga meliputi sarana pembuangan sampah, di mana tempat sampah yang tersedia kuat, kedap air, mudah diangkat, sampah diangkut dalam frekuensi angkutan minimum $1 \mathrm{kali} / \mathrm{hari}$, serta tempat sampah tidak menjadi perindukan serangga. Ruang makan selalu bersih, ukuran ruang cukup memadai, tersedia fasilitas cuci tangan, dan dilengkapi fasilitas meja dan kursi yang cukup. Ruang dapur memiliki tempat pencucian peralatan, penyimpanan tempat bahan makanan dan tempat pengolahan. Dilengkapi alat pengeluaran udara panas dan bau-bauan. Dilengkapi dengan sungkup asap, luas dapur minimal 40\% dari luas ruang makan. Pesantren bebas dari jentik nyamuk.

\section{Kondisi Sanitasi Pesantren}

Kondisi lingkungan, bangunan, dan fasilitas sanitasi antara satu pesantren dengan pesantren lainnya berbeda-beda. Perbedaan ini bisa jadi berasal dari sejarah pendirian masingmasing pesantren. Ada pesantren yang sejak awal pendiriannya memang dirancang, seperti lokasinya ditentukan, letak bangunannya ditata, dan fasilitas sanitasinya direncanakan, sebaliknya ada juga pesantren yang didirikan karena tuntutan kebutuhan masyarakat akan sebuah lembaga pendidikan keagamaan sehingga lokasi pesantren seperti itu berada di lingkungan padat penduduk. Karenanya bangunan pesantren dibangun di tengah keterbatasan lahan, dan fasilitas sanitasinya pun terbatas. Karena itu, hasil studi terhadap sanitasi pesantren dapat menghasilkan simpulan yang berbeda-beda.

Studi Kuspriyanto (2013) terhadap beberapa pesantren di Kabupaten Pasuruan misalnya menyimpulkan sebagian pesantren masih mengandalkan air sungai untuk memenuhi kebutuhan air warga pesantren, sebagian lain menggunakan air yang berasal dari sumur pompa atau gali. Penyediaan air bersih yang berasal dari air sungai untuk kebutuhan MCK apalagi untuk memasak memiliki risiko terkena penyakit mengingat sungai saat ini pada umumnya menjadi tempat pembuangan berbagai limbah. Kamar yang disediakan pesantren sebagai hunian santri masih tergolong padat. Idealnya hunian yang baik sebesar $\geq 4 \mathrm{~m}^{2} /$ orang. Namun, pesantren di Kabupaten Pasuruan dihuni rata-rata sebesar 1,51 $\mathrm{m}^{2} /$ santri per kamar.

Kondisi luas ventilasi ruangan pesantren rata-rata juga berada di bawah minimal yang ditetapkan oleh Kementerian Kesehatan yakni $6,69 \%$ dari luas lantai. Kondisi ventilasi ruang yang demikian tidak mampu menjadi sirkulasi udara yang baik. Akibatnya kondisi ruang pada umumnya lembab. Kelembaban ruangan memang tidak semata-mata merupakan dampak dari kondisi ventilasi udara, tetapi juga merupakan dampak dari kondisi iklim di mana pesantren berada, tingkat kepadatan ruangan, intensitas sinar matahari yang masuk dalam ruangan dan sebagainya.

Berbeda dengan hasil studi di atas, studi Murtako dan Khomsatun (2016) di salah satu pesantren di Kabupaten Tegal menjelaskan bahwa hampir semua aspek sanitasi pesantren telah memenuhi syarat kesehatan mulai lingkungan pesantren, kondisi bangunan, penyediaan air bersih, pengelolaan makan dan minuman, pengelolaan sampah, pengendalian vektor dan binatang pengganggu. Kecuali aspek hunian santri yang masih padat dan pembuangan air limbah di pesantren kurang baik.

Sementara studi Febriani dkk (2016) di salah satu pesantren di Kota Banjar menjelaskan bahwa dilihat dari aspek kesehatan lingkungan, lokasi pesantren berada pada lokasi terhindar dari pencemaran dan tidak berada di daerah banjir. Halaman pesantren tidak selalu dalam keadaan bersih, tetapi upaya untuk menjaga kebersihan tetap dilakukan pada pagi hari. Dilihat dari aspek kesehatan bangunan, lantai pesantren ini menggunakan bahan yang belum terlalu kuat, tidak kedap air, dan terdapat beberapa kamar yang permukaan lantainya tidak rata. Dinding pesantren juga masih banyak yang tidak kedap air dan kotor. Beberapa atap masih banyak yang bocor. Ketinggian langit-langit gedung di pesantren ini sudah mencapai lebih dari 2,75 meter, warna langit-langit dicat putih dan bersih. Tangga yang digunakan pada setiap gedung di pesantren lebih dari $30 \mathrm{~cm}$, memiliki tinggi anak 
tangga maksimal $20 \mathrm{~cm}$ dan memiliki pegangan tangan dan lebar tangga lebih dari $150 \mathrm{~cm}$. Pintu di pesantren ini belum dapat mencegah masuknya binatang pengganggu. Jendela juga belum dilengkapi gorden. Pencahayaan pada tiap kamar di pesantren tersebut bisa digunakan untuk membaca dengan mata normal. Kondisi ruang pada tiap gedung di pesantren tidak pengap, tidak bau dan bising. Kamar tidur pada tiap gedung di pesantren memiliki peralatan tidur bersih, penataan barang-barang rapi, luas kamar tidur $4 \mathrm{x}$ $4 \mathrm{~m}, 5 \times 4 \mathrm{~m}$, dan $4,5 \mathrm{~m}^{2}$, namun jumlah penghuni dalam satu kamar cukup padat rata-rata 15-50 orang. Ukuran ventilasi di pesantren kurang dari $15 \%$ dari luas lantai.

Air bersih yang ada di pesantren berwarna kuning, sedikit berbau, dan berasa. Jarak antara sarana air bersih dengan sumber pencemaran kurang dari 10 meter. Tempat wudhu bersih dan terpelihara, menggunakan air yang mengalir, terpisah antara pria dan wanita, dan tersedia dalam jumlah yang cukup. Akan tetapi, pesantren belum memiliki sarana pengelolaan air limbah. Air limbah mengalir tidak lancar, saluran air limbah menggunakan sistem terbuka dan tidak kedap air, sehingga air limbah di pesantren memiliki potensi untuk mencemari lingkungan sekitar.

Jarak kamar mandi dari sumber air dengan penampungan kotoran tidak mencapai jarak 10 $\mathrm{m}$, kebersihan kamar mandi kurang terjaga dan menimbulkan bau, serta perbandingan jumlah kamar mandi dengan jumlah penghuni belum memadai, saat ini baru ada 73 buah kamar mandi untuk 1.122 orang santri. Pesantren belum memiliki sarana untuk pengelolaan sampah. Sarana pembuangan sampah masih terbuka dan menjadi tempat perindukan serangga seperti lalat. Pesantren ini memang tidak menyediakan ruang makan khusus, santri dan santriwati makan di dalam kamar masing-masing. Pesantren menyediakan dapur tetapi belum dilengkapi dengan sungkup asap. Namun, secara keseluruhan lingkungan pesantren bebas jentik nyamuk.

Studi Mahardika (2017) tentang sanitasi pesantren pada 24 pesantren di Kota Kudus menyimpulkan bahwa sebagian pesantren
(12,67\%) belum menyediakan air bersih dengan jumlah yang cukup untuk memenuhi kebutuhan santri mereka. Banyak pesantren (50\%) yang kurang memperhatikan pengelolaan jamban mereka, rata-rata jamban mereka kotor, jumlahnya tidak sesuai dengan jumlah santri, tidak tersedia pembersih di setiap WC, lantainya tidak permanen dan licin, dan kerap kali ada serangga atau vektor. Banyak pesantren (67\%) kurang peduli pada pengelolaan sampah, tempat sampahnya tidak terbuat dari bahan yang kuat, tidak kedap air. Tempat sampah tidak tertutup, jumlah sampah yang menumpuk cukup banyak karena sampah dikosongkan kadang hanya satu minggu sekali. Banyak pesantren (50\%) kurang memerhatikan pembuangan limbah, saluran air limbahnya tidak tertutup, air limbah tidak mengalir dengan lancar, sebagian pesantren bahkan masih mengalirkan air limbahnya ke sungai.

Studi Adriansyah (2017) terhadap sanitasi pesantren di Lamongan menjelaskan bahwa saluran pembuangan air limbah pada pesantren yang dikaji berada dalam kondisi yang kurang baik. Kondisi kamar mandi dan WC juga kurang baik. Demikian pula kondisi pengelolaan sampahnya. Meskipun kondisi kamar santri dan ruang belajar cukup baik.

Studi yang penulis lakukan di tiga pesantren di Kalimantan Barat menunjukkan bahwa dua pesantren, yakni Pesantren Ushuluddin di Kota Singkawang dan Pesantren Darussalam Sengkubang di Kabupaten Pontianak memiliki sanitasi pesantren yang telah memenuhi syarat kesehatan. Pesantren Ushuluddin di Singkawang lokasinya terhindar dari banjir, halamannya luas tertata rapi, dan ada batas yang jelas antara letak pesantren dengan letak hunian penduduk sekitar. Ruang kelas memiliki jendela dan ventilasi yang baik yang memungkinkan pergantian udara. Ruang kamar menggunakan lantai yang kuat, kedap air, dan memiliki ventilasi yang lebar sehingga memudahkan pergantian udara. Ratarata kamar dihuni 15-20 santri. Ruang makan santri bersih dan tertata rapi, tersedia tempat cuci tangan. Ruang dapur juga bersih meski tidak dilengkapi dengan sungkup asap tetapi 
karena dapur cukup luas dan terpisah dengan bangunan lainnya, tungkup asap menjadi tidak diperlukan. Kamar mandi dan WC cukup bersih. Air limbah dari kamar mandi mengalir ke selokan meski selokan masih terbuka, belum memiliki pengelolaan limbah dan pengelolaan sampah. Pesantren menyediakan tempat sampah di depan kamar masing-masih santri dan tertutup. Salah satu kendala yang dihadapi pesantren ini adalah ketersediaan air bersih selama ini menggunakan air PDAM dan air hujan, mengingat air dari sumur gali atau pompa sulit didapat karena memang tanah di mana pesantren berada tidak memungkinkan untuk menggali sumur. Pesantren pernah mencoba menggali sumur bor, namun hingga kedalaman $100 \mathrm{~m}$, air tidak berhasil ditemukan.

Kondisi serupa juga penulis temukan di Pesantren Darussalam di Sengkubang Kabupaten Pontianak. Lokasi pesantren cukup strategis jauh dari kepadatan hunian penduduk, terhindar dari risiko bencana alam dan banjir. Pesantren memiliki pagar sebagai batas pemisah dengan lingkungan sekitar. Pesantren tersebut juga memiliki halaman yang cukup luas. Kondisi bangunan cukup bagus, dinding dan lantainya kuat. Atapnya tidak bocor. Ventilasi ruang kamar yang dihuni santri cukup luas dan memudahkan terjadinya pergantian udara sehingga kamar tidak pengap. Pintu kamar cukup baik, jendela kamar cukup lebar meski belum dilengkapi dengan gorden. Ruang kamar mandi, WC, dan tempat wudhu cukup bersih, dan tidak bau. Pesantren belum memiliki pengelolaan limbah, air limbah mengalir ke selokan yang belum tertutup, di depan setiap kamar santri tersedia tempat sampah, santri diminta selalu menjaga kebersihan kamar, kamar mandi, WC, dan tempat wudhu dengan sistem piket. Air bersih yang tersedia berasal dari air PDAM dan air hujan. Kamar santri dihuni 1520 santri.

Kondisi sanitasi dua pesantren di atas berbeda dengan kondisi sanitasi Pesantren aljihad di Kota Pontianak. Lokasi pesantren berada di perkampungan yang padat penduduk, tidak ada batas yang jelas baik berupa pagar atau sejenisnya yang memisahkan pesantren dengan hunian pendudukan setempat. Pesantren tidak memiliki halaman dan tempat parkir. Ruang kamar pesantren dihuni cukup padat, ventilasi ruang kamar kurang memungkinkan terjadinya sirkulasi udara sehingga cukup pengap, ketersediaan kamar mandi dan jamban tidak memadai dengan jumlah santri yang tersedia. Ruang kelas juga cukup pengap karena ventilasinya kurang memungkinkan terjadinya pergantian udara. Masjid pesantren cukup besar tetapi tidak memiliki halaman parkir, tempat wudhu bersih. Pesantren tidak memiliki pengelolaan limbah, air limbah dialirkan ke selokan yang terbuka dan airnya tidak mengalir dengan lancar, berlumpur hitam, dan mengeluarkan bau yang kurang sedap. Pesantren juga tidak memiliki tempat pengelolaan sampah. Sampah pesantren diangkut oleh petugas khusus setiap satu hari sekali untuk dibawa ke tempat pembuangan akhir. Air yang digunakan untuk memenuhi kebutuhan mandi, mencuci, berwudhu berasal dari air hujan, pesantren secara khusus membangun tandon besar untuk menampung air letak tandon air besar itu berada di bawah masjid. Air untuk minum berasal dari PDAM. Pesantren menyadari bahwa kebutuhan air bersih merupakan kebutuhan dasar yang mendesak bagi santri, jika air yang digunakan tidak bersih bisa jadi akan memunculkan berbagai risiko penyakit, karena itu pesantren sejak tahun 2017 menyediakan alat filter air untuk memfilter air yang berasal dari air hujan agar kualitas air menjadi lebih baik.

Studi tentang sanitasi pesantren di atas menjelaskan, pertama, bahwa kondisi sanitasi satu pesantren dengan pesantren lainnya berbeda-beda. Ada pesantren yang sebagian sanitasinya memenuhi syarat kesehatan. Ada juga pesantren yang sebagian sanitasinya belum memenuhi syarat kesehatan. Kedua, banyak pesantren yang belum memiliki kesadaran akan pentingnya kesehatan sanitasi dasar pesantren. Ketiga, banyak pesantren yang belum memiliki sarana pengelolaan sampah dan pengelolaan limbah. Keempat, sebagian pesantren belum memperhatikan pentingnya penyediaan air bersih untuk memenuhi kebutuhan santri.

Perbedaan kondisi sanitasi antara satu 
pesantren dengan pesantren lainnya merupakan hal yang perlu dimaklumi. Sebab kualitas sanitasi pesantren ditentukan oleh beberapa faktor, antara lain faktor sejarah, kemampuan finansial pesantren dan diskursif pengelola pesantren. Faktor sejarah dalam konteks ini adalah sejarah pendirian sebuah pesantren. Ada pesantren yang berdiri di tengah keterbatasan lahan. Pengelola pesantren tidak membayangkan bahwa pengajian yang dilakukan di rumahnya kemudian berubah menjadi pesantren karena tuntutan santri untuk belajar agama kepadanya. Mesti dengan lahan terbatas sang pendiri pesantren tidak mampu menolak kehadiran santri untuk belajar agama kepadanya. Pesantren seperti ini pada umumnya tidak dirancang sejak awal untuk mendirikan sebuah pesantren dengan fasilitas sanitasi yang baik, mulai dari kamar tidur santri, kamar mandi, dapur, jamban dan lain sebagainya. Bagi pesantren seperti ini, yang terpenting adalah bagaimana pembelajaran agama yang diselenggarakan di pesantren dapat berjalan dengan baik, santri dapat tinggal di asrama pesantren dengan kondisi dan fasilitas yang sederhana. Ketika santri kian hari kian bertambah banyak, di situlah kemudian muncul problem sanitasi. Problem tersebut mulai dari kepadatan hunian kamar tidur, kelembaban ruangan, ketersediaan air bersih, kebersihan jamban dan pengolahan limbah serta pengelolaan sampah. Sebaliknya pesantren yang memiliki sanitasi yang memadai, sejarah pendiriannya berbeda dengan pesantren yang disebut pertama. Pada umumnya pengelola pesantren telah memiliki rancangan pembangunan yang baik, memiliki lahan yang cukup dan memiliki finansial yang cukup untuk mendirikan sebuah pesantren. Tata letak bangunan dan fasilitas sanitasi telah ditentukan sejak awal.

Ajaran Islam sarat dengan pesan kesehatan, kebersihan individu, dan lingkungan (Muhammad dkk, 2006) Ajaran-ajaran tersebut menjadi materi ajar dalam beberapa bidang kajian keilmuan Islam di pesantren, seperti bidang fikih dan tafsir. Tetapi terjadi gap antara das sein dan das sollen, antara pengetahuan santri yang dimiliki warga pesantren tentang ajaran Islam yang menyerukan untuk memelihara lingkungan, menjaga kesehatan dan kebersihan dengan perilaku keseharian warga pesantren yang menurut beberapa studi kurang memelihara lingkungan, menjaga kesehatan dan kebersihan. Pada pesantren tertentu bisa jadi kesenjangan itu terjadi karena padatnya aktivitas santri dalam proses pembelajaran sehingga tidak memungkinkan mereka untuk memelihara lingkungan, menjaga kesehatan dan kebersihan. Selain itu, kesenjangan muncul karena tidak ada kurikulum khusus yang mengajarkan warga pesantren tentang ramah lingkungan. Ajaran Islam tentang lingkungan seperti telah dijelaskan terdapat dalam beberapa bidang studi seperti fikih dan tafsir. Akan tetapi diskusi-diskusi soal ramah lingkungan, kesehatan, dan kebersihan belum banyak dilakukan sehingga wacana lingkungan, kesehatan, dan kebersihan belum menjadi diskusi dominan dalam kesadaran santri. Akibat minimnya kajian-kajian ramah lingkungan, kesehatan dan kebersihan berdampak pada kurangnya perhatian warga pesantren terhadap pengelolaan limbah dan sampah, dan penyediaan air bersih bagi santri.

Saat ini, sampah bukan saja menjadi permasalahan di lingkungan rumah tangga, tetapi juga menjadi permasalahan di lingkungan pesantren. Pesantren dengan 1.000 santri di dalamnya, setiap hari menghasilkan sampah yang tidak kecil. Pada umumnya sampah yang telah menumpuk di tempat pembuangan sampah dibakar. Pembakaran sampah tersebut melahirkan polusi udara di lingkungan pesantren. Oleh karena itu, pesantren perlu memikirkan bagaimana mereka melakukan pengolahan sampah di pesantren. Salah satu upaya yang bisa dilakukan adalah dengan membangun bank sampah. Beberapa pesantren telah berupaya menerapkan konsep bank sampah tersebut, di antaranya adalah pesantren Nurul Jadid (Faid \& Jasri, 2017). Selain pengembangan bank sampah, pengelolaan sampah di pesantren dapat dilakukan dengan bekerja sama dengan dinas kebersihan kabupaten/ kota seperti yang dilakukan oleh Pesantren Darunnajah Bogor, atau mengolah sampah untuk tujuan ekonomis seperti yang dilakukan oleh Pesantren Al-Imdad di Yogyakarta (Syaifullah, 2011). Upaya lain yang juga perlu dilakukan 
adalah mengenalkan pengelolaan sampah dengan pendekatan 3R ke pesantren-pesantren. Seperti diketahui pendekatan pengelolaan sampah dengan konsep 3R adalah upaya mengurangi (reduce), menggunakan kembali (reuse) dan mendaur ulang sampah (recycle) (Kementerian PU, 2010:1). Pendekatan ini belum banyak disosialisasikan ke pesantren. Karena itu, tidak heran jika sebagian besar pengelola pesantren belum memahami konsep pengelolaan sampah tersebut (Samin dkk, 2013).

Selain pengenalan pengelolaan sampah, pesantren juga perlu mengenal pengelolaan air bersih. Sebagian besar pesantren menyediakan air bersih dari sumur pompa. Sebagian kecil pesantren menyediakan air bersih dari PDAM, dan masih ada pesantren yang menyediakan air bersih dari sungai. Secara umum air sumur atau air sungai yang disediakan pesantren untuk keperluan santri tidak melalui proses pengolahan. Artinya air langsung digunakan oleh santri baik untuk konsumsi atau kebutuhan lainnya. Air sumur yang tidak diolah terlebih dahulu memiliki efek negatif bagi kesehatan manusia, selain memiliki efek terhadap pakaian dan peralatan lainnya. Di antara pesantren yang telah memperoleh pelatihan pengelolaan air bersih adalah Pesantren As-shiddiqiyah Kabupaten Kubu Raya (Priad \& Sitompul, 2018: 21). Pemerintah perlu memberi perhatian lebih terhadap ketersediaan air bersih di pesantren. Air bersih bagi warga negara menurut PBB (2010) merupakan hak asasi manusia. Sebagai hak asasi manusia, negara berkewajiban hadir untuk menghormati, melindungi, dan memenuhi hak warga negara atas air (Mungkasa, 2010: 10). Warga pesantren tentu saja termasuk warga negara Indonesia perlu dipenuhi hak mereka atas air bersih.

\section{Dampak bagi Kesehatan Santri}

Salah satu gangguan kesehatan yang paling sering dialami santri yang mengenyam proses pendidikan di pesantren adalah gangguan kesehatan kulit berupa sakit skabies, atau yang populer dikenal dengan sebutan kudis, yakni penyakit infeksi kulit menular. Gejara orang yang didera sakit kudis menurut Slamet (1994: 103-104), kulitnya terasa sangat gatal pada 40 malam hari, pada kulit ditemukan bintik-bintik kecil yang berisi cairan bening. Penyakit ini diakibatkan oleh tungau Sarcoptes Scabiei yang memasuki kulit, memakan jaringan kulit dan menaruh telur-telurnya di dalam kulit. Telur akan menetas dalam waktu 4-8 hari, dan nympha-nya menjadi dewasa dalam waktu dua minggu. Karena sangat gatal, penderita terus menggaruk-garuk kulitnya, karena terus digaruk kulit kemudian didera infeksi sekunder.

Selain kudis, masih ada gangguan kesehatan lain yang lazim dialami santri di pesantren, seperti sesak nafas, demam, batuk-pilek, influenza, diare, dan maag. Dari berbagai gangguan kesehatan itu, yang khas pesantren adalah skabies (kudis). Karena khas pesantren, gangguan kulit ini sampai melahirkan mitos, belum sah menjadi santri jika belum kena kudis. Kudis bahkan dipandang sebagai tolok ukur bagi seorang pembelajar untuk menjadi seorang santri. Gangguan kudis juga dipandang sebagai kondisi di mana santri telah siap menempuh dan menerima proses pembelajaran pesantren (Syauqi, 2014). Secara ilmiah pandangan tersebut tentu belum bisa dipertanggungjawabkan, tetapi kudis sebagai mitos telah diterima santri sebagai sesuatu yang memang harus dialaminya. Di samping melahirkan mitos, gangguan kudis juga dipandang sebagai cobaan seorang santri dalam menuntut ilmu di pesantren. Karena itu di pesantren tertentu gangguan kudis ini disebut jarban (Arab) yang dalam bahasa Indonesia bermakna cobaan.

Karena sakit skabies banyak diderita santri di pesantren, banyak peneliti yang tertarik untuk menjelaskan sebab-sebabnya. Mayrora dkk (2018: 100) misalnya menyimpulkan bahwa salah satu penyebab munculnya sakit kudis di pesantren adalah sanitasi pesantren yang belum memenuhi syarat kesehatan. Sementara secara spesifik Ibadurrahmi, Veronica, dan Nugrohowati (2016: 33) melihat bahwa kepadatan hunian asrama pesantren merupakan salah satu faktor penyebab penularan skabies di kalangan santri. kesimpulan senada juga dikemukakan oleh Ratnasari dan Sungkar (2014: 7), menurutnya skabies merupakan penyakit yang berhubungan dengan kepadatan penghuni asrama pesantren 
dan perilaku kebersihan santri. Menurut Ma'rufi, Keman, dan Notobroto (2015: 11) ketersediaan air bersih, kondisi kamar mandi, kondisi jamban, kepadatan hunian kamar tidur dan kelembaban ruangan merupakan faktor dominan yang berperan dalam penularan dan tingginya angka prevalensi penyakit skabies di antara santri di pesantren.

Dari hasil studi di atas dapat dikatakan bahwa sanitasi yang tidak memenuhi syarat kesehatan memberikan dampak terhadap kesehatan santri di pesantren. Santri yang hidup dengan sanitasi yang belum memenuhi syarat kesehatan rentan terkena skabies dan jenis sakit lainnya seperti diare, maag, sesak nafas (Bahraen, 2012) serta ISPA (Astuti, 2018). Harus dikatakan bahwa tidak semua santri yang tinggal di pesantren kemudian otomatis terkena beberapa penyakit tersebut, hal seperti itu bisa jadi karena mereka memiliki sistem kekebalan tubuh yang baik, atau bisa juga karena mereka sudah mengalami proses adaptasi. Santri telah beradaptasi dengan sanitasi pesantren yang belum memenuhi syarat kesehatan tersebut sehingga tubuhnya menjadi kebal terhadap skabies. Adaptasi seperti itu dapat terjadi dengan beberapa proses salah satunya melalui proses fisiologi (Soemarwoto, 2004: 45). Dalam konteks pesantren, santri bisa jadi mengalami proses adaptasi fisiologi tersebut, karena hidup dalam lingkungan pesantren yang sanitasinya belum memenuhi syarat kesehatan dalam tubuhnya berkembang kekebalan terhadap sakit skabies. Meskipun begitu, tidak berarti bahwa pengelola pesantren boleh mengabaikan kondisi sanitasi pesantren mereka yang belum memenuhi syarat kesehatan itu, sehingga santri yang hidup di pesantren dapat terhindar dari berbagai gangguan kesehatan. Pengelola pesantren justru dituntut untuk selalu memperhatikan sanitasi pesantrennya agar selalu dalam kondisi bersih dan sehat.

Selain sanitasi, hal lain yang berdampak bagi kesehatan santri adalah Perilaku Hidup Bersih dan Sehat (PHBS) di pesantren. Ramdan, Iswari, dan Wijaya (2013: 1) menjelaskan bahwa sebagian besar santri belum memiliki kesadaran untuk mencegah dirinya agar tidak sakit. Hal demikian tampak pada sikap santri yang tak terlalu peduli akan PHBS. Hal senada juga dijelaskan Sofia dan Widad (2016) yang mengatakan bahwa PHBS sebagian besar santri berada dalam kategori tidak baik. Sementara menurut Parman, Rachman, dan Pratama (2017) sebagian besar santri pesantren yang terkena skabies karena kurang menjaga kebersihan kulit, tangan, kuku, genital, pakaian, handuk, dan tempat tidur mereka.

Pengetahuan santri tentang kebersihan tentu tidak bisa dipandang rendah, karena mereka memperoleh pengetahuan tentang kebersihan dari berbagai materi ajar keagamaan seperti fikih, hadis, dan tafsir. Dalam studi fikih, hal yang pertama kali dikaji adalah soal berwudhu. Dalam kajian tentang wudhu, air bersih dan suci adalah hal pertama yang perlu diperhatikan. Ajaran tentang wudhu sejatinya ajaran tentang kesucian dan kebersihan. Setiap muslim yang akan melaksanakan ibadah salat, ia diwajibkan untuk berwudhu dengan air yang suci dan bersih. Pertanyaannya kemudian mengapa ajaran untuk menjaga kesucian dan kebersihan yang ada dalam ajaran wudhu itu tidak tampak dalam perilaku sehat dan bersih santri di pesantren? Tidak mudah untuk menjawab pertanyaan itu. Ajaran untuk menjaga kesucian dan kebersihan yang ada dalam ajaran wudhu tentu saja memberikan dampak pada PHBS santri di pesantren. Tetapi PHBS masing-masing santri tidak sama. Ada santri yang selalu menjaga kesehatan dan kebersihan dirinya, sementara ada juga santri yang tidak terlalu peduli terhadap kesehatan dan kebersihan dirinya. Ketidakpedulian santri terhadap kesehatan dan kebersihan dirinya tentu tidak bisa dijadikan dasar bahwa wudhu tidak berdampak pada perilaku bersih dan sehat santri. Banyak faktor yang mendorong seorang santri untuk peduli atau tidak peduli terhadap kebersihan, di antaranya adalah faktor pembiasaan atau habituasi yang dialami santri sejak dalam lingkungan keluarga mereka masing-masing. Jika seorang santri berasal dari keluarga yang menerapkan pembiasaan hidup bersih dan sehat sejak dini, di pesantren pun ia selalu peduli dengan kebersihan dan kesehatan dirinya. Sebaliknya jika ia berasal dari keluarga yang tidak memberikan pengalaman habituasi 
dengan sendirinya ia juga tidak terlalu peduli dengan kebersihan dan kesehatan dirinya. Karena itu, pengelola pesantren perlu menerapkan pola PHBS di kalangan santri, salah satunya melalui sistem piket kebersihan di asrama masing-masing santri, santri juga perlu dilatih dan dibiasakan dengan berbagai aktivitas yang mendukung pola hidup bersih dan sehat, seperti memberikan waktu khusus kepada santri untuk berolahraga.

\section{Kebijakan Pemerintah}

Ada dua kebijakan yang digulirkan pemerintah untuk mengatasi masalah kesehatan dan lingkungan di pesantren. Pertama, kebijakan tentang Pos Kesehatan Pesantren dariKementerian Kesehatan. Program ini diluncurkan pada 2006. Kedua, kebijakan tentang Eco-Pesantren dari Kementerian Lingkungan Hidup dan Kehutanan (KLHK) yang diluncurkan pada 2008.

\section{a. Pos Kesehatan Pesantren}

Pos Kesehatan Pesantren (Poskestren) merupakan salah satu bentuk upaya kesehatan bersumber daya masyarakat di lingkungan pondok pesantren. Poskestren diselenggarakan dengan prinsip dari, oleh, dan untuk warga pondok pesantren. Pelayanan yang dilakukan oleh Poskestren bersifat promotif (peningkatan) dan preventif (pencegahan) tanpa mengabaikan aspek kuratif (pengobatan) dan rehabilitatif (pemulihan kesehatan). Poskestren dibina oleh Puskesmas setempat. Secara umum Poskestren ditujukan untuk mewujudkan kemandirian warga pondok pesantren dan masyarakat sekitar dalam PHBS. Diamanatkan dalam Peraturan Menteri Kesehatan (Permenkes) Nomor 1 Tahun 2013 tentang Pedoman Penyelenggaraan dan Pembinaan Pos Kesehatan Pesantren (Poskestren) bahwa secara khusus Poskestren bertujuan untuk meningkatkan pengetahuan warga pondok pesantren dan masyarakat sekitarnya tentang kesehatan, meningkatkan sikap dan PHBS bagi warga pondok pesantren dan masyarakat sekitarnya, meningkatkan peran serta aktif warga pondok pesantren dan warga masyarakat sekitarnya dalam penyelenggaraan upaya kesehatan, dan memenuhi layanan kesehatan dasar bagi warga pondok pesantren dan masyarakat sekitarnya.
Sasaran Poskestren adalah pondok pesantren dan masyarakat pondok pesantren meliputi warga pondok pesantren (santri, kiai, pimpinan, pengelola dan pengajar di pondok pesantren termasuk wali santri), masyarakat di lingkungan pondok pesantren, tokoh masyarakat (tokoh agama Islam, pimpinan lembaga swadaya masyarakat (LSM) dan pimpinan organisasi kemasyarakatan lainnya di lingkungan pondok pesantren), serta petugas kesehatan dan stakeholders terkait lainnya. Ruang lingkup kegiatan Poskestren dalam Permenkes Nomor 1 Tahun 2013 tersebut meliputi pelayanan kesehatan dasar yang mengutamakan upaya promotif dan preventif tanpa meninggalkan upaya kuratif dan rehabilitatif dalam batas kewenangan Poskestren. Selain itu, Poskestren juga melakukan upaya pemberdayaan warga pondok pesantren dan masyarakat sekitar dalam bidang kesehatan serta peningkatan lingkungan yang sehat di pondok pesantren dan wilayah sekitarnya, pemberdayaan santri sebagai kader kesehatan (santri husada), dan kader siaga bencana (santri siaga bencana) (Permenkes RI, No 1, 2013:8).

Poskestren berfungsi sebagai wadah pemberdayaan masyarakat di bidang kesehatan, dalam alih informasi, pengetahuan dan keterampilan, dari petugas kepada warga pondok pesantren dan masyarakat sekitarnya, dan antarsesama pondok pesantren dalam rangka meningkatkan PHBS; sebagai wadah untuk mendekatkan pelayanan kesehatan dasar kepada warga pondok pesantren dan masyarakat sekitarnya; sebagai wadah pembelajaran tentang nilai dan ajaran agama Islam dalam menghadapi permasalahan kesehatan.

Manfaat Poskestren bagi pesantren antara lain tersedianya layanan dan akses kesehatan dasar; penyebaran informasi kesehatan; pengembangan dan perluasan kerja sama pondok pesantren dengan instansi terkait; terpeliharanya sarana sanitasi lingkungan. Sementara bagi warga pesantren dan masyarakat sekitarnya, memperoleh kemudahan untuk mendapatkan informasi, pengetahuan dan pelayanan kesehatan dasar; memperoleh bantuan secara profesional dalam pemecahan masalah kesehatan; mendapat informasi awal tentang 
kesehatan; dapat mewujudkan kondisi kesehatan yang lebih baik bagi warga pondok pesantren dan masyarakat sekitarnya. Sementara bagi kader Poskestren, mendapatkan informasi lebih awal tentang kesehatan; dapat mewujudkan aktualisasi dirinya untuk membantu warga pondok pesantren dan masyarakat sekitarnya dalam menyelesaikan masalah kesehatan yang ada di lingkungannya (Permenkes RI, No 1, 2013:10).

Kebijakan Poskestren yang digulirkan pemerintah tersebut sangat ideal, tetapi implementasi kebijakan tersebut tidak selalu dapat mencapai tujuan idealnya. Hal itu dapat diketahui dari studi Nasrullah (2016) di salah satu pesantren di Padang yang menyimpulkan bahwa pelaksanaan Poskestren di salah satu pesantren di kota tersebut belum mampu mewujudkan Poskestren yang ideal sebagaimana yang diinginkan oleh Permenkes. Beberapa faktor yang menjadi penyebab tidak terwujudnya Poskestren yang ideal itu adalah belum adanya pendanaan yang memadai, belum ada pencatatan yang representatif, belum ada pelaporan kegiatan yang kontinu dan dokumentasi kegiatan yang lengkap. Sementara Kusnawati(2013:1) melihatbahwa proses pelaksanaan pemberdayaan masyarakat melalui program Poskestren belum mampu menjadi stimulus bagi masyarakat untuk mengembangkan sumber daya internalnya. Selain itu, keberhasilan pemberdayaan masyarakat dipengaruhi antara lain oleh pengetahuan, partisipasi, motivasi, dukungan, kepemimpinan, komunitas potensial, kerja sama, dan kebijakan.

Menurut Rachmawaty, Rosmelia, Rochmah, dan Lusiana (2018:1-5), untuk mewujudkan pesantren yang sehat tidaklah mudah. Poskestren membutuhkan sumber daya manusia yang relevan, salah satunya relawan kesehatan pesantren. Karena itu, pembentukan relawan kesehatan pesantren yang terlatih merupakan upaya penting dalam meningkatkan derajat kesehatan pesantren. Banyak tugas yang dapat diemban oleh relawan tersebut satu di antaranya adalah pengendalian penyakit menular seperti skabies yang memang lazim diderita warga pesantren. Relawan poskestren juga perlu melakukan pengobatan optimal, sosialisasi perilaku hidup bersih dan sehat, serta upaya promotif berkesinambungan.

Studi Wijaya dan Adriansyah (2018) tentang manajemen Poskestren di Pesantren al-Fitrah Surabaya, menjelaskan bahwa ada beberapa kendala yang dihadapi pesantren dalam melaksanakan program Poskestren. Di antara beberapa kendala itu adalah tidak tersedianya waktu yang cukup bagi para pengelola Poskestren untuk menjalankan semua program yang telah ditetapkan. Proses pembelajaran di pesantren cukup padat sehingga pengelola Poskestren tidak bisa fokus untuk menjalankan programprogramnya. Selain waktu, kendala lain yang dihadapi adalah belum tersedianya sumber daya manusia yang relevan dengan fungsi Poskestren. Puskesmas setempat juga belum melakukan fungsi pengawasan dan pembinaan secara optimal terhadap Poskestren. Fungsi pengawasan dan pembinaan tersebut diperlukan pihak Poskestren agar mereka dapat membenahi kekurangannya.

Studi Shalihah (2015) di Poskestren Ruhul Islam Anak Bangsa di Aceh Besar menjelaskan bahwa Poskestren yang ada pada pesantren tersebut belum mampu menjalankan fungsinya secara baik. Salah satu program yang perlu terus dilakukan secara terus menerus oleh Poskestren adalah sosialisasi hidup sehat dan bersih di pesantren. Studi Wahyudin dan Arifin (2015) tentang Poskestren di salah satu pesantren tradisional di Jampang Tengah menjelaskan bahwa keberadaan Poskestren di pesantren tradisional itu membantu pesantren dalam mewujudkan warga pesantren untuk hidup sehat dan bersih. Sosialisasi sanitasi diri dan lingkungan pesantren yang dilakukan oleh Poskestren memberikan pengetahuan kepada warga pesantren untuk menjaga kesehatan dan kebersihan lingkungan sekitar, membudayakan pola perilaku hidup sehat. Mendorong untuk gemar berolahraga meskipun hanya sebentar, membiasakan santri mengkonsumsi air yang matang, menyarankan santri untuk istirahat dengan cukup dan menggunakan alas tidur dengan kasur atau karpet.

Dari beberapa studi di atas dapat dikatakan bahwa pemerintah perlu memberikan perhatian yang lebih terhadap pelaksanaan program 
Poskestren di pesantren. Poskestren yang telah didirikan perlu bimbingan, binaan, pengawasan dari pemerintah agar Poskestren yang ada di pesantren dapat memberikan kontribusi kepada warga pesantren. Keterbatasan sumber daya manusia yang dihadapi Poskestren perlu diantisipasi agar keterbatasan itu tidak berlarutlarut sehingga mematikan fungsi Poskestren yang telah didirikan. Warga pesantren memandang Poskestren sejatinya dapat diandalkan dalam membentuk sikap dan PHBS di kalangan warga pesantren. Akan tetapi, jika berbagai keterbatasan yang dihadapi Poskestren tidak segera diantisipasi, bisa jadi Poskestren kehilangan momentum dalam memberdayakan kesehatan warga pesantren.

\section{b. Eco-Pesantren}

Eco-Pesantren merupakan model pendidikan lingkunganhidupdilingkungan pondok pesantren. Eco-Pesantren bertujuan meningkatkan kesadaran bahwa ajaran Islam merupakan pedoman yang sangat penting dalam mewujudkan sikap dan perilaku ramah lingkungan, mendorong penerapan ajaran Islam dalam kegiatan seharihari, sosialisasi materi lingkungan hidup dalam aktivitas pondok pesantren, mewujudkan kawasan pondok pesantren yang baik, bersih, dan sehat, memberdayakan komunitas pondok pesantren untuk meningkatkan kualitas lingkungan yang Islami, berdasarkan al-Quran dan al-Sunnah, meningkatkan aktivitas yang mempunyai nilai tambah baik nilai ekonomi, sosial, dan ekologi; menjadikan pondok pesantren sebagai pusat pembelajaran (central of excellence) yang berwawasan lingkungan bagi komunitas pesantren dan masyarakat sekitar (Aulia, Narulita, Firdaus, dan Mardiah, 2018: 79).

Program dan kegiatan yang dikembangkan dalam Eco-Pesantren antara lain berupa kemaslahatan, kebersamaan, keterbukaan, kesetaraan, kejujuran, keadilan, dan kelestarian lingkungan hidup, program dan kegiatan tersebut merujuk pada ajaran al-Quran, al-Sunnah, dan nilai-nilai yang ada dalam kitab-kitab salaf. Banyak manfaat yang diperoleh pesantren yang mengikuti program Eco-Pesantren antara lain, pesantren dapat meningkatkan efisiensi pelaksanaan kegiatan operasional pondok pesantren dan penggunaan berbagai sumber daya, penghematan sumber dana melalui pengurangan konsumsi berbagai sumber daya, meningkatkan proses belajar mengajar yang lebih nyaman dan kondusif bagi warga pondok pesantren; menciptakan kebersamaan bagi warga pondok pesantren, sekaligus meningkatkan kesadaran dan kesejahteraan masyarakat sekitar, menghindari berbagai risiko dampak lingkungan dengan meningkatkan aktivitas yang memiliki nilai tambah bagi pondok pesantren, menjadi tempat pembelajaran bagi generasi muda tentang nilai-nilai pemeliharaan dan pengelolaan lingkungan hidup yang baik dan benar. Pesantren yang telah berhasil melaksanakan program ini menurut Kementerian Lingkungan Hidup (2014) terlihat pada beberapa indikator berikut: memiliki kebijakan ramah lingkungan, memiliki kurikulum lingkungan berbasis alam, pengembangan kegiatan ekstrakurikuler berbasis tadabbur alam, dan memiliki pengelolaan sarana dan prasarana pendukung pondok pesantren.

Beberapa studi tentang pelaksanaan EcoPesantren menjelaskan bahwa pesantren belum sepenuhnya memahami urgensi pelaksanaan EcoPesantren sebagai upaya melahirkan generasi muda yang memiliki kesadaran lingkungan. Hal itu terlihat misalnya pada salah satu pesantren di Lamongan Jawa Timur. Meskipun telah menerapkan program Eco-Pesantren tetapi belum sepenuhnya mampu melaksanakan program tersebut secara baik. Pesantren tersebut belum memiliki kurikulum khusus tentang pendidikan lingkungan. Meskipun demikian pesantren sudah berupaya untuk meningkatkan kebersihan dan kesehatan lingkungan pesantren (Aulia, Narulita, Firdaus, \& Mardiah, 2018:73-87). Program EcoPesantren meningkatkan sikap warga pesantren untuk menjaga lingkungan demi kehidupan yang lebih baik (Nawawi, 2017). Dalam pandangan Mangunjaya (2012) dalam konteks EcoPesantren, KLHK perlu menyusun program yang lebih baik, program tersebut ditujukan untuk meningkatkan kapasitas pengelolaan lingkungan di pesantren bukan program pengajaran tentang Islam dan lingkungan. Karena santri sejatinya 
telah memiliki pemahaman yang baik tentang Islam, bahwa Islam merupakan agama yang menganjurkan untuk ramah terhadap lingkungan, namun mereka masih jarang mempraktikkan ajaran tersebut dalam bentuk praktis keseharian.

Beberapa studi di atas menjelaskan bahwa program Eco-Pesantren yang digulirkan pemerintah memiliki arti penting bagi pesantren, utamanya dalam meningkatkan kesadaran warga pesantren tentang ramah lingkungan. Akan tetapi program ini perlu aksi yang lebih konkret, misalnya memberikan pelatihan-pelatihan pengelolaan lingkungan, pengelolaan limbah, dan pendampingan warga pesantren dalam pengelolaan sampah.

\section{Simpulan}

Sebagian besar fasilitas sanitasi yang ada pada beberapa pesantren yang menjadi fokus dalam kajian ini belum memenuhi syarat kesehatan. Sebagian pesantren tersebut bahkan belum memandang bahwa fasilitasi sanitasi sebagai aspek penting bagi proses belajar di pesantren. Sanitasi pesantren yang buruk berdampak pada kesehatan santri. Gangguan kesehatan yang acap kali menimpa santri di antaranya adalah skabies, diare, dan ISPA. Ada kebijakan yang digulirkan pemerintah untuk membantu pesantren keluar dari masalah sanitasi, yaitu Pos Kesehatan Pesantren dari Kementerian Kesehatan dan Eco-Pesantren dari Kementerian Lingkungan Hidup. Pesantren mengapresiasi kedua kebijakan ini sebagai perhatian pemerintah terhadap pesantren, namun belum semua pesantren yang ada di Indonesia dapat mengakses programprogram tersebut. Pos Kesehatan Pesantren setidaknya dapat mengembangkan wawasan warga pesantren urgensi hidup bersih dan sehat untuk mencegah datangnya gangguan kesehatan bagi warga pesantren. Sementara Eco-Pesantren dapat memperluas wawasan warga pesantren agar ramah terhadap lingkungan.

\section{Rekomendasi}

Pemerintah perlu terus memperkuat program Pos Kesehatan Pesantren dan EcoPesantren dan berupaya memperluas jangkauan penerapan program tersebut. Pemerintah juga perlu melakukan pendataan berapa pesantren yang telah memperoleh atau mengikuti program Pos Kesehatan Pesantren agar pemerintah dapat melakukan evaluasi terhadap program yang telah dilaksanakan dan berapa pesantren yang telah memperoleh dan mengikuti program tersebut mengingat besarnya jumlah pesantren yang tersebar di berbagai wilayah di Indonesia. Saat ini RUU tentang Pesantren dan Pendidikan Keagamaan sedang memasuki masa pembahasan di Komisi VIII, banyak kalangan berharap RUU tersebut dapat membantu pesantren meningkatkan kualitas pendidikannya, kualitas sarana dan prasarana yang dimilikinya. Namun isu sanitasi pesantren yang sehat belum mendapat perhatian dalam RUU tersebut, karena itu, dalam pembahasan RUU tersebut aspek sanitasi pesantren menjadi perhatian agar pesantren memiliki sanitasi yang baik dan sehat. 


\section{DAFTAR PUSTAKA}

Adriansyah, A. A. (2017). Keterkaitan antara sanitasi pondok pesantren dengan kejadian penyakit yang dialami santri di Pondok Pesantren Sunan Drajat. Medical Technology and Public Health Journal (MTPH Journal) | 4 MTPH Journal, 01(01).

Astuti, N.D. (2018). Hubungan Perilaku Santri dan Kondisi Lingkungan Fisik dengan Kejadian ISPA di Pondok Pesantren Assalafi Al-Fithrah Surabaya. Jurnal Kesehatan Lingkungan, 10(2), 233-242. Diakses dari https://e-journal.unair. ac.id/JKL/article/download/10189/5791.

Aulia, R. N., Narulita, S., Firdaus, M. M, \& Izzatul. (2018). Pengelolaan Lingkungan Berbasis Pesantren (Studi Kasus di Pondok Pesantren SPMAA Lamongan Jawa Timur). PLPB: Jurnal Pendidikan Lingkungan dan Pembangunan Berkelanjutan, IX(1).

Bahraen, R. (2012). Beberapa Masalah Kesehatan yang sering Muncul di Pondok Pesantren. Diakses dari https://muslimafiyah.com/beberapamasalah-kesehatan-yang-sering-muncul-dipondok-pesantren.html, pada 6 Mei 2019.

Bungin, B. (2018). Metode Penelitian Kualitatif. Jakarta: Prenada Media.

Faid, M. \& Jasri, M. (2017). Sistem Informasi Pengolahan Sampah Di Pondok Pesantren Nurul Jadid. Artikel Seminar Nasional Inovasi dan Aplikasi Teknologi di Industri, ITN Malang, 4 Februari.

Febriani, A. dkk. (2016). Gambaran Ketersediaan Sanitasi Dasar Di Pondok Pesantren Miftahul Huda Al-Azhar Citangkolo Desa Kujangsari Kota Banjar Tahun 2016 (Tugas Stase IKAKOM I). Program Studi Kedokteran Fakultas Kedokteran dan Kesehatan Universitas Muhammadiyah Jakarta, Jakarta.

Ibadurrahmi, H., Veronica, S., \& Nugrohowati, N. (2016). Faktor-faktor yang Berpengaruh Terhadap Kejadian Penyakit Skabies pada Santri di Pondok Pesantren Qotrun Nada Cipayung Depok Februari Tahun 2016. Jurnal Profesi Medika, 10(1), 33-45.

Kementerian Lingkungan Hidup. (2014). Ecopesantren Bergerak: Bismillah. Diakses dari http://www.menlh.go.id/eco-pesantrenbergerakbismillah/, pada 30 Oktober 2015.

Kusnawati, E. (2013). Pemberdayaan Masyarakat Pondok Pesantren Melalui Pos Kesehatan Pesantren Di Kabupaten Tulungagung (Tesis). Universitas Gadjah Mada, Yogyakarta.
Kuspriyanto. (2013). Pengaruh Sanitasi Lingkungan dan Perilaku Sehat Santri terhadap Kejadian Skabies di Pondok Pesantren Kabupaten Pasuruan Jawa Timur. Jurnal Geografi, 11(22), 64-73.

Madjid, N. (1997). Bilik-Bilik Pesantren. Jakarta: Paramadina.

Mangunjaya, F. M. (2012). Desain Ekopesantren dalam Kerangka Pembangunan Berkelanjutan. Diakses dari https://www.academia. edu/3119460/Eco_Pesantren_Design_on_the Framework_of_Sustainable_Development.

Ma'rufi, I., Keman, S., \& Notobroto, H. B. (2005). Faktor Sanitasi Lingkungan Yang Berperan Terhadap Prevalensi Penyakit Scabies Studi pada Santri di Pondok Pesantren Kabupaten Lamongan. Jurnal Kesehatan Lingkungan Unair, 2(1) 2005.

Mayrora, C. T., dkk. (2018). Pengaruh Sanitasi Lingkungan Terhadap Prevalensi Terjadinya Penyakit Scabies Di Pondok Pesantren Matholiul Huda Al Kautsar Kabupaten Pati. Jurnal Kedokteran Diponegoro, 7(1), 100-112, Diakses dari https:// ejournal3.undip.ac.id/index.php/medico/article/ view/19354.

Muhammad, A. S., dkk. (2006). Fiqih Lingkungan. Jakarta: Conservation International Indonesia.

Mungkasa, O. (2010). Majelis Umum PBB Sahkan Resolusi Hak Asasi atas Air. Percik, Edisi III, 2010, 5-9.

Murtako, J.A., \& Khomsatun. (2016). Deskripsi Sanitasi Pondok Pesantren Ma'hadut Tholabah Kabupaten Tegal Tahun 2016. Bulletin Keslingmas, 36 (3) 2017. Diakses dari ejournal.poltekkes smg.ac.id/ojs/ index.php/keslingmas/article/download/2994/627

Nasrullah. (2016). Pelaksanaan Manajemen Poskestren Di Pondok Pesantren Darul Funun El-Abbasiyah Padang Japang. Jurnal al-Fikrah, IV(2).

Nawawi, M., Gunawati, D., \& Sunarto. (2017). Peningkatan Sikap Peduli Lingkungan Melalui Program Eco-pesantren Di Pondok Pesantren Nurul Haramain Nw Narmada Kabupaten Lombok Barat. Prosiding Seminar Nasional Pendidikan Biologi dan Saintek Ke-2, Universitas Muhammadiyah Surakarta, Surakarta.

Parman, H., Rachman, I. \& Pratama, A. (2017). Faktor Risiko Hygiene Perorangan Santri Terhadap Kejadian Penyakit Kulit Skabies Di Pesantren Albaqiyatushshalihat Tanjung Jabung Barat Tahun 2017, Jurnal Ilmiah Universitas Batanghari Jambi, 17(3), 243 - 252. 
Peraturan Menteri Kesehatan tentang Pedoman Penyelenggaraan dan Pembinaan Pos Kesehatan Pesantren (2013).

Priadi, E. \& Sitompul, J. M. T. (2018). Pengelolaan Air Bersih di Pesantren As-Shiddiqiyah dan Panti Asuhan Al-Haq Kecamatan Sungai Kakap Kabupaten Kubu Raya, Al-Khidmah I, 17-23.

Ramdan, A. A., Iswari, R., \& Wijaya, A. (2013). Pola Penyakit Santri di Pondok Pesantren Modern Assalamah. Solidarity: Journal of Education, Society and Culture, 2 (1), 1-8.

Ratnasari, A. F. \& Sungkar, S. (2014). Prevalensi Skabies dan Faktor-faktor yang Berhubungan di Pesantren X, Jakarta Timur, eJurnal Kedokteran Indonesia, 2(1) April 2015,7-12.

Rachmawaty, F. J., Rosmelia, Rochmah, F. S. N., \& Lusiyana, N. (2018). Peran Rekestren (Relawan Kesehatan Pesantren) dalam Meningkatkan Derajat Kesehatan Pondok Pesantren. Diakses dari https://dspace.uii.ac.id/bitstream/ handle/123456789/11145.

Samin, dkk. (2013). Penerapan Konsep 3R sebagai Upaya Minimasi Volume Sampah Padat Perkotaan di Pondok Pesantren Al-Mizan Lamongan. DEDIKASI, 10, Mei, 45 - 54, diakses dari http:// ejournal.umm.ac.id/index.php/dedikasi/article/ view/1758.

Shalihah, N. (2015). Gambaran Status Kesehatan Santri Pada Pondok Yang Memiliki Pos Kesehatan Pesantren di Pesantren Ruhul Islam Anak Bangsa Aceh Besar (Skripsi). Universitas Syiah Kuala, Aceh.

Slamet, J. S. (1994). Kesehatan Lingkungan. Yogyakarta: Universitas Gajah Mada Press.

Soemarwoto, O. (2004). Ekologi, Lingkungan Hidup dan Pembangunan. Jakarta: Djambatan.

Sofia, D. \& Widad, S. (2016). Survei Perilaku Hidup Bersih dan Sehat terhadap Santri. Oksitosin Kebidanan, III(2), 113-117.

Suanta, M. (2016). Pengaruh Sanitasi Lingkungan Tempat Tinggal dan Karakteristik Sosial Ekonomi Rumah Tangga Terhadap Terjadinya Diare pada Balita di NTT (Analisis Lanjut Data Susenas 2012). Jurnal Bumi Lestari, 16(2), 119-130.

Surahmawati \& Rusmin, M. (2015). Gambaran Kualitas Fisik Bakteriologis Udara dalam Ruang dan Gejala ISPA di Pondok Pesantren Bahrul Ulum Kabupaten Gowa Tahun 2014. Higiene, 1(2), 84-91.
Syaifullah, M. (2011). Al Imdad, Pesantren Pengolah Sampah. Diakses dari https://nasional.tempo.co/ $\mathrm{read} / 332643 /$ al-imdad-pesantren-pengolah-sampah/ full\&view $=$ ok.

Syauqi, M.I, (2014). Berkah Sakit Kudis di Pesantren. Diakses dari http://www.nu.or.id/post/read/55429/ berkah-penyakit-kudis-di-pesantren.

Wahid, A. (1997). Pesantren sebagai Subkultur. Diakses dari https://santrigusdur.com/2018/05/pesantrensebagai-subkultur/, pada 2 Mei 2019.

Wahyudin, U. \& Arifin, H. S. (2015). Sosialisasi Sanitasi Diri dan Lingkungan di Pesantren Salafi Melalui Pos Kesehatan Pesantren (Poskestren) Dalam Membentuk Sikap Santri Terhadap Sanitasi, Jurnal Kajian Komunikasi, 3(2), 148-153.

Wijaya, S. \& Adriansyah, A. A. (2018). Analisis Pelaksanaan Manajemen Pos Kesehatan Pesantren (Poskestren) Studi Di Pondok Pesantren Assalafi Al Fitrah Kedinding, Kota Surabaya (Project Report). Universitas Nahdlatul Ulama, Surabaya.

NU Online. (2018, Oktober, 03). UU Pesantren Kembalikan Fungsi dan Peran Penting Pesantren, diakses dari http://www.nu.or.id/post/ $\mathrm{read} / 96680 /$ ruu-pesantren-kembalikan-fungsidan-peran-penting-pesantren. 